\title{
25 Research Soure \\ Identification of Porcine circovirus type (PCV2) and type 3 (PCV3), Porcine 2 parvovirus (PPV) in swine by multiplex PCR test
}

\section{Thoai Kim Tran}

Nong Lam University

Trang Thi Thanh Nguyen

Nong Lam University

Hiep Lai Xuan Vu

University of Nebraska Lincoln

Phat Xuan Dinh ( $\nabla$ dinhxuanphat@hcmuaf.edu.vn )

Nong Lam University https://orcid.org/0000-0003-3589-7252

\section{Research article}

Keywords: Swine, sows, reproductive disorders, Porcine circovirus type 2 (PCV2), Porcine circovirus type 3 (PCV3), Porcine parvovirus (PPV), multiplex PCR (mPCR)

Posted Date: May 11th, 2020

DOI: https://doi.org/10.21203/rs.3.rs-19714/v1

License: @ (i) This work is licensed under a Creative Commons Attribution 4.0 International License. Read Full License 


\section{Abstract}

Background : Aiming to simultaneously detect three important viruses known to be involved in reproductive problems of sows, a multiplex PCR (mPCR) test was developed to provide rapid diagnosis of porcine circovirus type 2 and 3 (PCV2, PCV3) and to illustrate parvovirus (PPV) prevalence in sow herds.

Methods : Three pairs of specific primers were designed to target PCV2 Cap gene, PCV3 Cap gene and PPV NS1 gene, with predicted mPCR products of 702 bp, 267 bp and $380 \mathrm{bp}$, respectively.

Results : The detection limit of mPCR was 100 copies/ reaction per target gene. Sequencing of mPCR products performed with clinical serum samples accurately confirmed results. The mPCR was run against a panel of 94 swine serum samples whose infection status had been pre-determined by commercial real-time PCR kits.

Overall, the mPCR results matched $100 \%$ with the real-time PCRs.

Conclusions: The developed mPCR test functions successfully and can be used in routine rapid diagnosis of PCV2, PCV3 and PPV.

\section{Introduction}

Reproductive disorders are among the most concerned problems in sow herds, causing huge economic losses to swine producers. Many infectious pathogens are involved which include: Porcine parvovirus (PPV), porcine circovirus type 2 (PCV2) and porcine circovirus type 3 (PCV3), a newly discovered viral pathogen [1].

PCV2 and PCV3 belong to the family Circoviridae. They are non-enveloped and single-circular DNA viruses [1, 2]. PCV2 has been proved to play significant roles in different swine syndromes such as Postweaning multisystemic wasting syndrome (PMWS), Porcine dermatitis and nephropathy syndrome (PDNS), or Porcine Circovirus associated diseases (PCVAD) $[3,4,5,6]$. The virus was first identified in western Canada in a case of wasting disease using electron microscopy, immunohistochemical, and in situ hybridization methods [5]. Later,multipleother publications confirmed the circulation and the pathogenesis of PCV2 in swine abortions, and births of weak piglets $[7,8,9,10]$. PCV3 was recently described in a case of PDNS syndrome in a sow farm in North Carolina (USA) [1]. The virus was found in samples of skin, kidney, lung, and lymph node without the existence of PCV2. From this observation, PCV3 is also suspected to play a pathogenic role in swine, especially in the sow herds although the evidence of its pathogenesis remains to be elusive. In addition to the causative lists of reproductive disorders in swine is PPV, a member of the Parvoviridae family, that was identified at the end of the 1960s $[11,12,13]$. Classical manifestations associated with a PPV infection of pregnant sows include stillbirths, mummification, embryonic death, and infertility, a condition that is collectively identified as SMEDI syndrome.

These three viruses are endemic in Vietnam and cause significant losses $[14,15,16]$. PPV was reported to be circulating in the Vietnamese swine herds since 1998 [17], while PCV2 and PCV3 were reported in 2005 and 2017 , respectively $[18,19]$.

Several conventional and real-time PCRs have been developed for molecular diagnosis of these three viruses $[20,21,22,23,24,25]$. However, those PCRs are designed for detection of a single viral agent at a time. Recently, duplex PCRs were developed for simultaneous detection of both PCV2 and PCV3 [26, 27, 28]. In the 
present study, we report the development and validation of a mPCR that allows simultaneous detection of these three important viruses in clinical samples.

\section{Materials And Methods}

\section{Controls and clinical samples}

Positive controls: DNA fragments of PCV3 Cap gene and PPV NS1 gene were synthesized by Integrated DNA Technologies (IDT - USA). DNA template of PCV2 was originally obtained from a field isolate followed by sequencing confirmation. The resulting sequence exhibited $99.72 \%$ identity to the previously reported PCV2 (Gene ID LC383449.1).

Unrelated pathogens for specificity evaluation: bacteria and viruses that are commonly present in the swine farms and potentially contaminated into the samples were used to confirm the specificity of the PCR. Staphylococcus aureus (ATCC 6338); Escherichia coli (E. coli (ATCC 25922)) were offered by Sanphar Vietnam laboratory (belonging to Erber group, Austria); Streptococcus suis and Clostridium perfringens were obtained from previous study [29]. Pseudorabies virus ( $g E$ gene were synthesized by Integrated DNA Technologies (IDT USA). The bacterial DNA was extracted with phenol-chloroform-isoamyl alcohol (25:24:1) solution (Cat\#P1037, Sigma; Cat\#25666, Merck).

Clinical samples: Ninety-four serum samples from sows were collected and used to evaluate this mPCR procedure. Each serum sample was pooled from five individual sows. All samples were submitted to the laboratory and the senders signed agreement for the laboratory to use result data for the purposes of teaching and publication. The infectious status of these 94 samples were predetermined by using commercial Realtime PCR kits or master mix, as per the manufacturers' instructions. The Realtime kit for PCV2 was PowerChek $^{\text {TM }}$ PCV2 Real-time PCR Kit (Cat\#R0809, Primerdesign), for PPV was PowerChek ${ }^{T M}$ ADV/PPV Realtime PCR Kit (Cat\#R0832, Primerdesign) and Luna® Universal qPCR Master Mix (Cat\#M3003S, NEB) was for PCV3.

\section{DNA preparation from clinical samples}

Serum samples were extracted by advanced phenol-chloroform method [30]. Two hundred microliters of a serum sample was mixed with $500 \mu$ l extraction buffer $(200$ mM Tris-HCl, pH 7.5; 25 mM EDTA; 250 mM NaCl and $0.5 \%$ SDS) and votexed vigorously, followed by incubation on ice for $15 \mathrm{~min}$. The mixture was centrifuged for $8 \mathrm{~min}$ at $4000 \mathrm{rpm}$ and the upper aqueous layer was collected and transferred to pre-chilled $1.5 \mathrm{~mL}$ tube, followed by the addition of $0.25 \mathrm{~mL}$ of phenol and $0.25 \mathrm{~mL}$ of chloroform/isoamyl-alcohol $(24: 1, v / v)$. After the tube was inverted several times and centrifuged at $14000 \mathrm{rpm}$ for $6 \mathrm{~min}$. The supernatant was then collected and transferred to a new tube, followed by an addition of $0.5 \mathrm{~mL}$ of chloroform/isoamyl-alcohol mixture (24:1, $V / V$ ) and centrifugation at $14000 \mathrm{rpm}$ for $3 \mathrm{~min}$. Finally, the upper aqueous layer was transferred to a clean 1.5 $\mathrm{ml}$ tube, followed by the addition of $1 \mathrm{~mL}$ absolute ethanol and incubation at $-20^{\circ} \mathrm{C}$ overnight to facilitate DNA precipitation. The DNA was then pelleted by centrifugation at $14000 \mathrm{rpm}$ for $30 \mathrm{~min}$, followed by a wash with 1 $\mathrm{mL}$ of $70 \%$ cold-ethanol. The pellet was allowed to air-dry at $40{ }^{\circ} \mathrm{C}$, dissolved in $30 \mu \mathrm{l} 1 \mathrm{X}$ tris-EDTA buffer, pH 8.0 and was stored at $-20^{\circ} \mathrm{C}$ for subsequent assays. 


\section{Primers}

Table 1 Primer sequences and estimated product sizes

\begin{tabular}{|c|c|c|c|c|c|}
\hline Virus & Primers & Gene & Primer sequences $\left(5^{\prime}-3^{\prime}\right)$ & $\begin{array}{l}\text { Product size } \\
\text { (bp) }\end{array}$ & Reference \\
\hline \multirow[t]{2}{*}{ PCV2 } & \multirow[t]{2}{*}{ PCV2 } & \multirow[t]{2}{*}{ Cap } & F:ATGACGTATCCAAGGAGGCG & \multirow[t]{2}{*}{702} & \multirow[t]{2}{*}{ Present study } \\
\hline & & & $\begin{array}{l}\text { R: } \\
\text { TTAAGGGTTAAGTGGGGGGTC }\end{array}$ & & \\
\hline \multirow[t]{2}{*}{ PCV3 } & \multirow[t]{2}{*}{ PCV3 } & \multirow[t]{2}{*}{ Cap } & F: TTCCGGGACATAAATGCT & \multirow[t]{2}{*}{267} & \multirow{2}{*}{$\begin{array}{l}\text { Lan Tian et al., (2017) } \\
\text { [31] }\end{array}$} \\
\hline & & & R: GGGCACACAGCCATAGAT & & \\
\hline \multirow[t]{2}{*}{ PPV } & \multirow[t]{2}{*}{ PPV } & \multirow[t]{2}{*}{ NS1 } & $\begin{array}{l}\text { F: } \\
\text { GCTTTAGCCTTGGAGCCGTGGA }\end{array}$ & \multirow[t]{2}{*}{380} & \multirow[t]{2}{*}{ Present study } \\
\hline & & & $\begin{array}{l}\text { R: } \\
\text { CGTGTTCTTTTGCTGCGGCGTC }\end{array}$ & & \\
\hline
\end{tabular}

The primers used in this study are listed in Table 1. The primers for amplification of PCV2 were designed based on the alignment of 65 PCV2 cap gene sequences recorded in the NCBI GenBank. This primer pair will result in a PCR product of $702 \mathrm{bp}$. The primers for amplification of PPV was designed based on the alignment of 67 PPV NS1 sequences recorded in the NCBI GenBank. The expected product size for the PPV PCR is $380 \mathrm{bp}$. Finally, the primers for amplification of PCV3 were obtained from Lan Tian et al. (2017) [30]. This pair of primers was designed based on the PCV3 cap gene with the expected product size of 267bp.

\section{Multiplex PCR (mPCR)}

After multiple rounds of optimization, a primer mix containing three primer pairs was created at a mixing ratio of 1 PPV: 2 PCV2 : 4 PCV3. Accordingly, the final concentrations of the PPV, PCV2 and PCV3 primer pairs in the mixture were $0.2 \mu \mathrm{M}, 0.4 \mu \mathrm{M}, 0.8 \mu \mathrm{M}$, respectively. The mPCR was performed in a $20 \mu$ l reaction volume containing $10 \mu$ l of DreamTaq 2X (Cat\#K1072, No MAN0012702, Thermo Scientific), $1.4 \mu$ l of the primer mix, 3 $\mu \mathrm{l}$ DNA template, and $5.6 \mu \mathrm{l}$ of nuclease free water (ThermoFisher). After initial denaturation at $94^{\circ} \mathrm{C}$ for $5 \mathrm{~min}$, 35 cycles were conducted at $94^{\circ} \mathrm{C}$ for $30 \mathrm{~s}, 56^{\circ} \mathrm{C}$ for $30 \mathrm{~s}$, and $72{ }^{\circ} \mathrm{C}$ for $40 \mathrm{~s}$, followed by a final extension at $72{ }^{\circ} \mathrm{C}$ for $5 \mathrm{~min}$. Ten microliters of amplified products werw then analyzed by electrophoresis in a $1.5 \%(\mathrm{~W} / \mathrm{V})$ agarose gel in 1X Tris-Boric-EDTA (TBE) containing Midori Green Advance DNA stain. A 1 Kb Plus DNA ladder (Invitrogen) was used as the molecular weight marker to indicate the sizes of the PCR products.

\section{Evaluation of the specificity of the MPCR}

Genomic DNA of Staphylococcus aureus (ATCC 6338); Escherichia coli (E. coli (ATCC 25922)); Streptococcus suis, Clostridium perfringens and Pseudorabies virus (PRV) $g E$ gene were used as templates in the mPCR to determine the specificity of the test. The concentration of DNA templates used in the reaction was $30 \mathrm{ng}$ per reaction in the cases of bacteria genomic template and and $10^{8}$ copy per reaction in the case of Pseudorabies gE gene. 


\section{Evaluation of the sensitivity of the MPCR}

Ten-fold serial dilutions of each positive control DNA templates ranging from $10^{7}$ to $10^{0}$ copies were used as the DNA template in the MPCR to estimate its limit of detection. The minimum number of template copies that enable successful amplification of each product was considered as its limit of detection.

\section{DNA sequencing}

Sequencing of each PCR product was performed by using both forward and reverse primers used in corresponding PCR (Table 1). The sequencing results were aligned with the reference PCV2 (accession no. MH470234.1), PCV3 (accession no. MK058529.1) and PPV (accession no. MK378155.1) using Clustal Omega program.

\section{Results}

\section{Optimal condition for the multiplex PCR}

Before combining the primers to form a mPCR, each primer pair was tested for its performance in individual PCRs at different annealing temperatures. Gel electrophoresis analysis indicated that only one single DNA product was generated for each individual PCR, with the product sizes of $267 \mathrm{bp}$ for PCV3, $380 \mathrm{bp}$ for PPV and $702 \mathrm{bp}$ for PCV2 (Fig 1). It appeared that the three primer pairs worked well at the annealing temperatures between $52{ }^{\circ} \mathrm{C}$ and $58{ }^{\circ} \mathrm{C}$. Subsequently, the annealing temperature of $56^{\circ} \mathrm{C}$ was chosen for mPCR. As shown in Fig. 2, the mPCR produced three amplicons that were clearly visible and easily distinguishable from each other. Importantly, the sizes of the amplicons were as expected and were similar to the ones observed in single PCRs (Fig. 2). Although the templates were the three positive control DNAs, the three products in this mPCR were recovered from agarose gel and subjected to sequencing. The sequencing results confirmed that the three pairs of primers were compatible, functioning accurately and without interfering with each other when combined in one reaction.

\section{Specificity, sensitivity and functioning under interfering conditions}

Next, we evaluated the specificity of the MPCR by running with unrelated DNA templates isolated from bacteria and/or viruses commonly found in pig farms which included Staphylococcus aureus, Escherichia coli, Streptococcus suis, Clostridium perfringens and Pseudorabies virus. Results showed that the three primer pairs did not cross-react with any of these DNA templates (Fig. 3A), indicating the established mPCR has expected specificity.

We then evaluated the sensitivity of the MPCR by running the assay against a set of 10 -fold serially diluted positive control DNA templates with the copy numbers ranging from $10^{7}$ to $10^{\circ}$ copies per reaction. As shown in Fig. 3B, three distinct DNA bands at expected molecular weights were observed at the concentration of $10^{2}$ copies per reaction. Thus the sensitivity of this MPCR ranks at the level of 100 copies/gene/reaction.

\section{Performance of the MPCR with clinical samples}


The ultimate aim of this experiment was to evaluate the diagnostic performance of the mPCR using real life clinical samples. Ninety-four sow serum samples whose infectious statuses were predetermined by using commercial real-time PCR kits were used to evaluate the MPCR. The DNA electrophoresis results of the first 18 samples were shown in Fig. 4 for demonstration purposes. Detailed information of the mPCR results is listed in Tables 2 and 3. The single infection rates for PCV2, PCV3 and PPV in these 94 samples were $43.6 \%, 39.4 \%$ and $55.3 \%$ respectively (Table 2 ). More importantly, the mPCR results matched $100 \%$ with the commercial real-time PCR results. The co-infection of three tested viruses (PCV2, PCV3 and PPV) were identified in $17.0 \%$ samples while the dual infection between PCV2 and PCV3; PCV3 and PPV, or PCV2 and PPV were detected in 7.4\%, $5.3 \%$, and $11.7 \%$ sample, respectively (Table 3 ).

\section{Sequence analysis of the PCR amplicons}


Table 2 Detection of clinical specimens by multiplex PCR and real-time PCR

\begin{tabular}{|c|c|c|c|c|c|c|c|c|}
\hline \multirow{2}{*}{$\begin{array}{l}\text { Pig } \\
\text { Farm }\end{array}$} & \multirow{2}{*}{$\begin{array}{l}\text { No. of } \\
\text { specimens }\end{array}$} & \multicolumn{3}{|c|}{ Multiplex PCR } & \multicolumn{3}{|c|}{ Real-time PCR } & \multirow{2}{*}{$\begin{array}{l}\text { Concordance } \\
\text { rate (\%) }\end{array}$} \\
\hline & & $\begin{array}{l}\text { PCV2 } \\
\text { positive } \\
(\%)\end{array}$ & $\begin{array}{l}\text { PCV3 } \\
\text { positive } \\
(\%)\end{array}$ & $\begin{array}{l}\text { PPV } \\
\text { positive } \\
\text { (\%) }\end{array}$ & $\begin{array}{l}\text { PCV2 } \\
\text { positive } \\
(\%)\end{array}$ & $\begin{array}{l}\text { PCV3 } \\
\text { positive } \\
(\%)\end{array}$ & $\begin{array}{l}\text { PPV } \\
\text { positive } \\
\text { (\%) }\end{array}$ & \\
\hline 1 & 5 & $1(20.0)$ & $3(60.0)$ & $2(40.0)$ & $1(20.0)$ & $3(60.0)$ & $2(40.0)$ & 100 \\
\hline 2 & 5 & $3(60.0)$ & $1(20.0)$ & $2(40.0)$ & $3(60.0)$ & $1(20.0)$ & $2(40.0)$ & 100 \\
\hline 3 & 5 & $2(40.0)$ & $0(0.0)$ & $4(80.0)$ & $2(40.0)$ & $0(0.0)$ & $4(80.0)$ & 100 \\
\hline 4 & 5 & $4(80.0)$ & $2(40.0)$ & $3(60.0)$ & $4(80.0)$ & $2(40.0)$ & $3(60.0)$ & 100 \\
\hline 5 & 5 & $2(40.0)$ & $3(60.0)$ & $4(80.0)$ & $2(40.0)$ & $3(60.0)$ & $4(80.0)$ & 100 \\
\hline 6 & 5 & $4(80.0)$ & $3(60.0)$ & $3(60.0)$ & $4(80.0)$ & $3(60.0)$ & $3(60.0)$ & 100 \\
\hline 7 & 5 & $4(80.0)$ & $3(60.0)$ & $4(80.0)$ & $4(80.0)$ & $3(60.0)$ & $4(80.0)$ & 100 \\
\hline 8 & 5 & $3(60.0)$ & $3(60.0)$ & $5(100)$ & $3(60.0)$ & $3(60.0)$ & $5(100)$ & 100 \\
\hline 9 & 5 & $3(60.0)$ & $3(60.0)$ & $5(100)$ & $3(60.0)$ & $3(60.0)$ & $5(100)$ & 100 \\
\hline 10 & 5 & $4(80.0)$ & $4(80.0)$ & $2(40.0)$ & $4(80.0)$ & $4(80.0)$ & $2(40.0)$ & 100 \\
\hline 11 & 5 & $2(40.0)$ & $2(40.0)$ & $2(40.0)$ & $2(40.0)$ & $2(40.0)$ & $2(40.0)$ & 100 \\
\hline 12 & 5 & $2(40.0)$ & $2(40.0)$ & $2(40.0)$ & $2(40.0)$ & $2(40.0)$ & $2(40.0)$ & 100 \\
\hline 13 & 5 & $0(0.0)$ & $2(40.0)$ & $1(20.0)$ & $0(0.0)$ & $2(40.0)$ & $1(20.0)$ & 100 \\
\hline 14 & 5 & $1(20.0)$ & $1(20.0)$ & $2(40.0)$ & $1(20.0)$ & $1(20.0)$ & $2(40.0)$ & 100 \\
\hline 15 & 5 & $1(20.0)$ & $0(0.0)$ & $4(80.0)$ & $1(20.0)$ & $0(0.0)$ & $4(80.0)$ & 100 \\
\hline 16 & 5 & $2(40.0)$ & $0(0.0)$ & $3(60.0)$ & $2(40.0)$ & $0(0.0)$ & $3(60.0)$ & 100 \\
\hline 17 & 5 & $1(20.0)$ & $1(20.0)$ & $1(20.0)$ & $1(20.0)$ & $1(20.0)$ & $1(20.0)$ & 100 \\
\hline 18 & 5 & $1(20.0)$ & $2(40.0)$ & $2(40.0)$ & $1(20.0)$ & $2(40.0)$ & $2(40.0)$ & 100 \\
\hline 19 & 4 & $4(25.0)$ & $2(50.0)$ & $1(25.0)$ & $4(25.0)$ & $2(50.0)$ & $1(25.0)$ & 100 \\
\hline Total & 94 & $\begin{array}{l}41 \\
(43.6)\end{array}$ & $\begin{array}{l}37 \\
(39.4)\end{array}$ & $\begin{array}{l}52 \\
(55.3)\end{array}$ & $\begin{array}{l}41 \\
(43.6)\end{array}$ & $\begin{array}{l}37 \\
(39.4)\end{array}$ & $\begin{array}{l}52 \\
(55.3)\end{array}$ & 100 \\
\hline
\end{tabular}


Table 3 Detection of the co-infection of clinical specimens by multiplex PCR

\begin{tabular}{|c|c|c|c|c|c|}
\hline $\begin{array}{l}\text { Pig } \\
\text { Farm }\end{array}$ & $\begin{array}{l}\text { No. of } \\
\text { specimens }\end{array}$ & $\begin{array}{l}\text { PCV2 and } \\
\text { PCV3 } \\
\text { positive } \\
\text { (\%) }\end{array}$ & $\begin{array}{l}\text { PCV3 and } \\
\text { PPV } \\
\text { positive } \\
\text { (\%) }\end{array}$ & $\begin{array}{l}\text { PCV2 and } \\
\text { PPV } \\
\text { positive } \\
(\%)\end{array}$ & $\begin{array}{l}\text { PCV2, PCV3 and PPV } \\
\text { positive } \\
\text { (\%) }\end{array}$ \\
\hline 1 & 5 & $0(0.0)$ & $0(0.0)$ & $0(0.0)$ & $1(20.0)$ \\
\hline 2 & 5 & $0(0.0)$ & $0(0.0)$ & $1(20.0)$ & $1(20.0)$ \\
\hline 3 & 5 & $0(0.0)$ & $0(0.0)$ & $1(20.0)$ & $0(0.0)$ \\
\hline 4 & 5 & $1(20.0)$ & $1(20.0)$ & $2(40.0)$ & $0(0.0)$ \\
\hline 5 & 5 & $1(20.0)$ & $1(20.0)$ & $0(0.0)$ & $1(20.0)$ \\
\hline 6 & 5 & $1(20.0)$ & $0(0.0)$ & $1(20.0)$ & $2(40.0)$ \\
\hline 7 & 5 & $0(0.0)$ & $1(20.0)$ & $1(20.0)$ & $3(60.0)$ \\
\hline 8 & 5 & $0(0.0)$ & $0(0.0)$ & $1(20.0)$ & $2(40.0)$ \\
\hline 9 & 5 & $0(0.0)$ & $0(0.0)$ & $0(0.0)$ & $3(60.0)$ \\
\hline 10 & 5 & $2(40.0)$ & $0(0.0)$ & $0(0.0)$ & $2(40.0)$ \\
\hline 11 & 5 & $1(20.0)$ & $0(0.0)$ & $0(0.0)$ & $0(0.0)$ \\
\hline 12 & 5 & $0(0.0)$ & $0(0.0)$ & $1(20.0)$ & $0(0.0)$ \\
\hline 13 & 5 & $0(0.0)$ & $0(0.0)$ & $0(0.0)$ & $0(0.0)$ \\
\hline 14 & 5 & $0(0.0)$ & $0(0.0)$ & $1(20.0)$ & $0(0.0)$ \\
\hline 15 & 5 & $0(0.0)$ & $1(20.0)$ & $0(0.0)$ & $0(0.0)$ \\
\hline 16 & 5 & $0(0.0)$ & $0(0.0)$ & $1(20.0)$ & $0(0.0)$ \\
\hline 17 & 5 & $0(0.0)$ & $0(0.0)$ & $0(0.0)$ & $0(0.0)$ \\
\hline 18 & 5 & $1(20.0)$ & $1(20.0)$ & $0(0.0)$ & $1(20.0)$ \\
\hline 19 & 4 & $0(0.0)$ & $0(0.0)$ & $1(20.0)$ & $0(0.0)$ \\
\hline Total & 94 & $7(7.4)$ & $5(5.3)$ & $11(11.7)$ & $16(17.0)$ \\
\hline
\end{tabular}

To further confirm the specificity of the mPCR assay, PCR products of PPV, PCV3 and PCV2 amplified from the field samples were excised from the agarose gel and subjected to DNA sequencing. The resulting sequences were $97 \%, 98.88 \%, 98.42 \%$ identity to the reference sequences for PCV2; PCV3 and PPV, respectively. The results clearly demonstrate that the mPCR specifically amplified the targeted viral DNA templates.

\section{Discussion}

Since its initial identification in the US [1], PCV3 has been subsequently, but almost simultaneously, found in vavious pig-producing countries. The $39.4 \%$ detection rate for PCV3 in our study was also comparable to other 
reports elsewhere, such as $44.2 \%$ in Korea [32]; $31.18 \%$ in Central China [33]; $50 \%$ in Germany [34]; 56.4\%, $37.4 \%, 14.8 \%$ in Denmark, Italy, Spain respectively [35]; $61.1 \%$ in United States [36]; and $47.8 \%$ in Brazil [37]. It is therefore possible that this virus had already emerged and spread through the global swine population before it was discovered in the US.

Co-infection between PCV2 and other swine pathogens are frequently detected in swine herds [38]. One of the plausible reasons for this is that PCV2 can suppress the host immune system, therefore, rendering the host more susceptible to infection with other pathogens. PPV is one of the common swine pathogens that are detected in PCV2 infected pigs [38]. Previous studies showed that co-infection of pigs with PCV2 and PPV is more effective in inducing PMWS disease than coinfection between PCV2 and other pathogens $[39,1,41]$. Consequently, PPV is often used in combination with PCV2 to induce PMWS in experimental studies [1]. Coinfection between PCV2 and PCV3 is also commonly observed. Several studies from China have reported the PCV2/PCV3 coinfection rates varying from 27.6-39.39\% [38]. While it has been demonstrated that PCV2, PCV3 and PPV are endemic in Vietnam, the co-infection rates of these 3 viruses in Vietnamese sow herds have not been studied. Currently, singleplex realtime PCRs are used for molecular detection of these viruses. The use of single-target real-time PCRs used to detect multiple pathogens within one sample significantly increases the diagnostic costs, thus, deterring swine producers from using this service. Therefore, we are interested in developing a quick and reliable mPCR that allow simultaneous detection of these three pathogens. The results indicate that the diagnostic performance of our MPCR is similar to that of commercial real-time PCRs that are currently used in Vietnam (Table 2). The detection limit of our MPCR is 100 copies of each target gene per reaction. Liu et al. (2015) established a mPCR to detect and differentiate of PCV2, Porcine reproductive and respiratory syndrome virus 2 (PRRSV-2), PPV and Pseudorabies virus in pigs with PMWS [42]. These authors reported that the sensitivity of their mPCR was $4.0 \times 10^{3}$ and $3.0 \times 10^{2}$ copies to PCV2 and PPV, respectively. Recently, Yang et al. (2018) developed a mPCR for simultaneous detection of PCV1, PCV2 and PCV3 with the detection limit of 50 copies of each target gene per reaction [43]. Thus, our mPCR herein reported has similar levels of sensitivity as compared to those reported in recent publications.

\section{Conclusions}

In summary, we successfully developed and validated a MPCR to simultaneously detect three common swine DNA viruses in clinical samples. This MPCR should provide quick and reliable molecular diagnosis of reproductive failure in sow herds.

\section{Declarations}

\section{Ethics approval and consent to participate}

Not applicable (written in the part of Clinical Samples)

\section{Consent for publication}

Not applicable (written in the part of Clinical Samples)

\section{Competeing interests}


The authors declare that they have no competing interests.

\section{Funding}

Funding source was from Nong Lam University Ho Chi Minh City, under the grant number CS-CB16-CNSH-02.

\section{Availability of data and materials}

Not applicable (all necessary data have been shown in the manuscript).

\section{Author's contributions}

TKT organized experiment, analysed data and established initial manuscript. TTTN collected samples and performed PCR assay. HLXV provided suggestion in research and substantially revised the manuscript. PXD initiated the project, supervised the study, and prepared the final manuscript.

\section{Acknowledgements}

We thank Fernando Osorio (University of Nebraska Lincoln) for helpful advises in study and writing the manuscript.

\section{References}

1. Palinski R, Piñeyro P, Shang P, Yuan F, Guo R, Fang Y, Byers E, Hause BM. A Novel Porcine Circovirus Distantly Related to Known Circoviruses Is Associated with PorcineDermatitis and Nephropathy Syndrome and Reproductive Failure. Virol. 2016;91. [CAS] [Article] [Google Scholar]

2. Tisciier I, Mields W, Wolff D, Vagt M, Griem W. Studies on Epidemiology and Pathogenicity of Porcine Circovirus. Arch. Virol. 1986;(91):271-276. [Article] [Google Scholar]

3. Allan GM, McNeilly F, Meehan BM, Kennedy S, Mackie DP, Ellis JA, Clark EG, Espuna E, Saubi N, Riera P. Isolation and characterisation of circoviruses from pigs with wasting syndromes in Spain, Denmark and Northern Ireland. Vet. Microbiol. 1999;66(2):115-23. [Article] [Google Scholar]

4. Allan GM, McNeilly E, Kennedy S, Meehan B, Moffett D, Malone F, Ellis J, Krakowka S. PCV-2-associated PDNS in Northern Ireland in 1990. Porcine dermatitis and nephropathy syndrome. Vet. Rec. 2000;146(24):711-712. [Article] [Google Scholar]

5. Ellis J, Hassard L, Clark E, Harding J, Allan G, Willson P, Strokappe J, Martin K, McNeilly F, Meehan B. Isolation of circovirus from lesions of pigs with postweaning multisystemic wasting syndrome. Can. Vet. J. 1998;39:44-51. [CAS] [Article] [Google Scholar]

6. Rosell C, Segales J, Ramos-Vara JA, Folch JM, Rodriguez-Arrioja GM, Duran CO, Balasch M, Plana-Duran J, Domingo M. Identification of porcine circovirus in tissues of pigs with porcine dermatitis and nephropathy syndrome. Vet. Rec. 2000;146:40-43. [Article] [Google Scholar]

7. West KH, Bystrom JM, Wojnarowicz C, Shantz N, Jacobson M, Allan GM. Myocarditis and abortion associated with intrauterine infection of sows with porcine circovirus 2. Vet. Diagn. Investig. Off Publ Am. Assoc. Vet. Lab. Diagn. Inc. 1999;11:530-532. [Article] [Google Scholar] 
8. Calsamiglia M, Fraile L, Espinal A, Cuxart A, Seminati C, Martı M,Mateu E, Domingo M, Segale's aJ. Sow porcine circovirus type 2 (PCV2) status effect on litter mortality in postweaning multisystemic wasting syndrome (PMWS). Vet. Sci. 2007;82:299-304. [Article] [Google Scholar]

9. Oropeza-Moe1 M, Oropeza Delgado AJ, Framstad T. Porcine circovirus type 2 associated reproductive failure in a specific pathogen free (SPF) piglet producing herd in Norway: a case report. Porcine Health Management. 2017;3(25). [CAS] [Google Scholar]

10. Chun KM, Ching Y, Chian-Ren J, Victor FP, Kuang-Sheng Y. Reproductive failure associated with coinfection of porcine circovirus type 2 and porcine reproductive and respiratory syndrome virus. Can. Vet. J. 2018;59:525-530. [CAS] [Google Scholar]

11. Cartwrigh S, Huck R. Viruses isolated in association with herd infertility abortions and stillbirths in pigs. Vet. Rec. 1967;81:196-197. [Google Scholar]

12. Cartwright SF, Lucas M, Huck R. A small haemagglutinating porcine DNA virus: I. Isolation and properties. J. Comp. Pathol. 1969:79. [Article] [Google Scholar]

13. Johnson R, Collings D. Experimental infection of piglets and pregnant gilts with a parvovirus. Vet. Rec. 1969;446-447. [Article] [Google Scholar]

14. Pham HQ. Study on Epidemiological and molecular characteristics of porcine Circovirus type 2 (PCV2) in pigs raised in Vietnam. PhD thesis. Vietnam National University of Agriculture, Vietnam, 2019. [Article]

15. Nguyen VG, Chung HC, Huynh TML, Cao TBP, Vu TN, Le VT, Pham HQ. Molecular Characterization of Novel Porcine Circovirus 3 (PCV3) in Pig Populations in the North of Vietnam. Gene. Genome. Res. 2018;1:24-32. [CAS] [Google Scholar]

16. Chu TP. Fetal dryness disease in wild boar due to Parvovirus and the preventive effect of Farrowsure $B$ vaccine. Graduation thesis of Veterinary Medicine. Thai Nguyen University of Agriculture and Forestry, Vietnam, [Article]

17. Pham H, Ho DC. The role of Porcine Parvovirus in reproductive disorder syndrome of pigs in some central provinces of Vietnam, researching on vaccine preparation. PhD thesis of Agriculture: 4.03.03, National Institute of Veterinary Research, Vietnam, [Article]

18. Lam TTH, Duong CM. Detection of Porcine circovirus type 2 in pigs at some intensive farms in Ho Chi Minh city and some adjacent provinces. Journal of Science and Technology of Agriculture and Forestry. 2005;2, 3. [Article]

19. Pham HQ, Nguyen VG, Nguyen TTT, Pham CH, Huynh TML. Study the circulation of new viruses (Porcine Circovirus 3 - PCV3) in pigs raised in some northern provinces of Vietnam. Vietnam Journal of Agricultural Science. 2017;15:1520-1528. [CAS] [Google Scholar]

20. Molitor TW, Oraveerakul K, Zhang QQ, Choi CS. Ludemann, L.R. Polymerase chain reaction (PCR) amplification for the detection of porcine parvovirus. J. Virol Methods. 1991;32:201-211. [Article] [Google Scholar]

21. Shibata I, Okuda Y, Yazawa S, Ono M, Sasaki T, Itagaki M, Nakajima N, Okabe Y, Hidejima I. PCR detection of Porcine circovirus type 2 DNA in whole blood,serum, oropharyngeal swab, nasal swab, and feces from experimentally infected pigs and field cases. J. Vet. Med. Sci. 2003;65:405-408. [Article] [Google Scholar]

22. Chen HY, Li XK, Cui BA, Wei ZY, Li XS, Wang YB, Zhao L, Wang XY. A TaqMan-based real-time polymerase chain reaction for the detection of porcine parvovirus. J. Virol. Methods. 2009;156:84-88. [Article] [Google 


\section{Scholar]}

23. Zhao K, Han F, Zou Y, Zhu L, Li C, Xu Y, Zhang C, Tan F, Wang J, Tao S, He X, Zhou Z, Tang X. Rapid detection of porcine circovirus type 2 using a TaqMan-based real-time PCR. Virol. J. 2010;7:374. [CAS] [Article] [Google Scholar]

24. Chen GH, Mai KJ, Zhou L, Wu RT, Tabg XY, Wu JL, He LL, Lan T, Xie QM, Sun Y, Ma JY. Detection and genome sequencing of porcine circovirus 3 in neonatal pigs with congenital tremors in South China. Emerg. Dis. 2017;1-5. [CAS] [Article] [Google Scholar]

25. Chen G, Tang X, Sun Y, Zhou L, Li D, Bai Y, Mai K, Li Y, Wu Q, Ma J. Development of a SYBR green-based real-time quantitative PCR assay to detect PCV3 in pigs. J. Virol. Methods. 2017;251:129-132. [CAS] [Article] [Google Scholar]

26. Yang K, Jiao Z, Zhou D, Guo R, Duan Z, Tian Development of a multiplex PCR to detect and discriminate porcine circoviruses in clinical specimens. B.M.C. Infect. Dis. 2019;19:778. [Article] [Google Scholar]

27. Wang Y, Fenga Y, Zhenga W, Nolla L, Portera E, Potterd M, Cinoa G, Peddireddia L, Liua X, Andersonb G, Bai J. A multiplex real-time PCR assay for the detection and differentiation of the newly emerged porcine circovirus type 3 and continuously evolving type 2 strains in the United States. J. Virol. Methods. 2019;269:7-12. [CAS] [Article] [Google Scholar]

28. Yu HQ, Cai XQ, Lin ZX, Li XL, Yue QY, Li R, Zhu XQ. Rapid and specific detection of porcine parvovirus using real-time PCR and High Resolution Melting (HRM) analysis. B.M.C. Vet. Res. 2015;11. [Article] [Google Scholar]

29. Nguyen DHM, Luong QTX, Hoang PT, Do DTT, Tran TK, Dinh PX. Detecting toxin genes of Clostridium perfringens isolated from diarrhea piglets using multiplex PCR. J.A.D. 2018;17:24-30. [Google Scholar]

30. Sambrook J, Green MR. Chapter 1: Isolation and Quantification of DNA. Molecular Cloning a laboratory manual, $4^{\text {th }}$; Cold Spring Harbor Laboratory, Cold Spring Harbor, NewYork, 2012; Volume 1, pp.2. [Google Scholar]

31. Lan T, Ma JY, Sun Y, Mai KJ. PCR (Polymerase Chain Reaction) primer for detecting and identifying Porcine circovirus 3 (PCV3) and detection method and detection kit. CN, 2017; [CAS] [Article]

32. Kwon T, Yoo SJ, Park C, Lyoo YS. Prevalence of novel porcine circovirus 3 in Korean pig populations. Vet. Microbiol. 2017;207:178-180. [CAS] [Article] [Google Scholar]

33. Xu PL, Zhang Y, Zhao Y, Zheng HH, Han HY, Zhang HX, Chen HY, Yang MF, Zheng LL. Detection and phylogenetic analysis of porcine circovirus type 3 in central China. Emerg. Dis.

2018;65:1163-1169. [CAS] [Article] [Google Scholar]

34. Prinz C, Stillfried M, Neubert LK, Denner J. Detection of PCV3 in German wild boars. Virol J.2019;16:1-7. [CAS] [Article] [Google Scholar]

35. Franzo G, Legnardi M, Hjulsager CK, Klaumann F, Larsen LE, Segales J, Drigo M. Full-genome sequencing of porcine circovirus 3 field strainsfrom Denmark, Italy and Spain demonstrates a high within-Europe genetic heterogeneity. Transbound. Emerg. Dis. 2018;65:602-606. [Article] [Google Scholar]

36. Arruda B, Piñeyro P, Derscheida R, Hause B, Byers E, Dion K, Long D, Sievers D, Tangen J, Williams T, Schwartz K. PCV3-associated disease in the United States swine herd. Emerg. Microbes. Infect. 2019;8: 684-698. [CAS] [Article] [Google Scholar] 
37. Saraiva GL, Vidigal PMP, Assao VS, Fajardo MLM, Loreto ALS, Fietto JRL, Bressan GC, Lobato ZIP, Almeida MRD, Silva-Júnior A. Retrospective Detection and Genetic Characterization of Porcine circovirus 3 (PCV3) Strains Identified between 2006 and 2007 in Brazil. Viruses. 2019;27(11). [CAS] [Article] [Google Scholar]

38. Ouyang T, Zhang X, Liu X, Ren L. Co-Infection of Swine with Porcine Circovirus Type 2 and Other Swine Viruses. Viruses. 2019;11:185. [Article] [Google Scholar]

39. Steiner E, Balmelli C, Gerber H, Summerfield A, McCullough K. Cellular adaptive immune response against porcine circovirus type 2 in subclinically infected pigs. B.M.C. Vet. Res. [Article] [Google Scholar]

40. Ha Y, Lee YH, Ahn KK, Kim B, Chae C. Reproduction of postweaning multisystemic wasting syndrome in pigs by prenatal porcine circovirus 2 infection and postnatal porcine parvovirus infection or immunostimulation. Vet. Pathol. 2008;45:842-848. [CAS] [Article] [Google Scholar]

41. Ostanello F, Caprioli A, di Francesco A, Battilani M, Sala G, Sarli G, Mandrioli L, McNeilly F, Allan GM, Prosperi S. Experimental infection of 3-week-old conventional colostrum-fed pigs with porcine circovirus type 2 and porcine parvovirus. Vet. Microbiol. 2005;108:179-186. [CAS] [Article] [Google Scholar]

42. Liu JK, Wei CH, Yang XY, Dai AL, Li XH. Simultaneous detection and differentiation of Porcine circovirus type 2, type 2 Porcine reproductive and respiratory syndrome virus, Porcine parvovirus and Pseudorabies virus in pigs with postweaning multisystemic wasting syndrome (PMWS) by multiplex PCR. Vet. Arhiv. 2015;85:511-521. [Article] [Google Scholar]

43. Yang K, Jiao Z, Zhou D, Guo R, Duan Z, Yuan F, Tian Y. Detection of porcine circoviruses in clinical specimens using multiplex PCR in Hubei, central China. PeerJ Preprints. 2018;6. [Article] [Google Scholar]

\section{Figures}

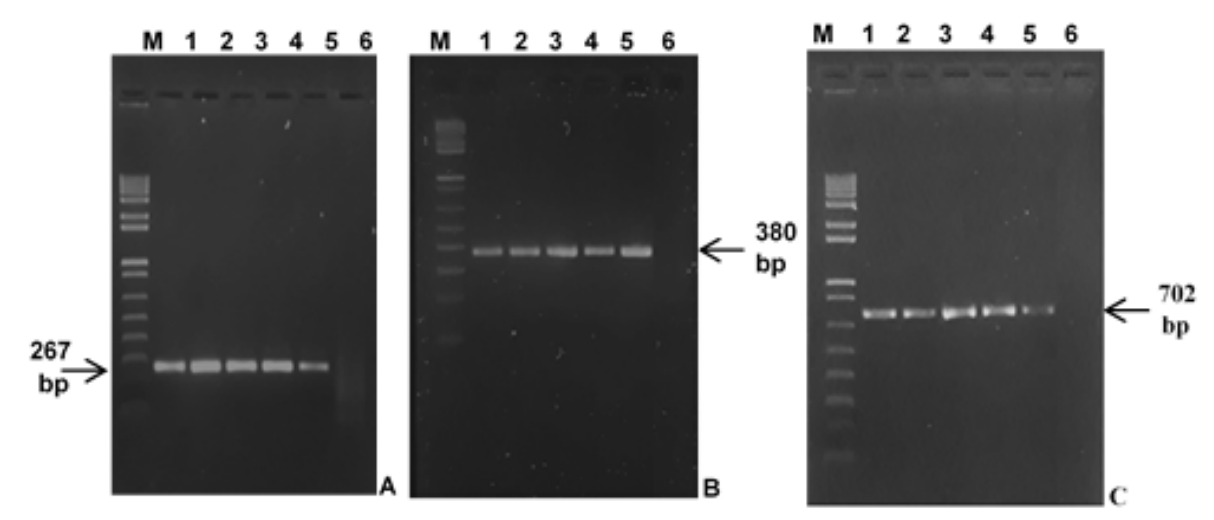

Figure 1. Optimization of annealing temperature in s-PCR. (A) PCV3, (B) PPV, (C) PCV2. M: DNA ladder $1 \mathrm{~Kb}$ plus, (1): $50^{\circ} \mathrm{C}$, (2): $52^{\circ} \mathrm{C}$, (3): $54^{\circ} \mathrm{C}$, (4): $56^{\circ} \mathrm{C}$, (5): $58^{\circ} \mathrm{C}$, (6): negative control with pure water: The thermal cycling conditions were: $94^{\circ} \mathrm{C} / 5 \mathrm{~min} ; 35$ Cycles of $94^{\circ} \mathrm{C} / 30 \mathrm{~s}, 56^{\circ} \mathrm{C} / 30 \mathrm{~s}$ and $72^{\circ} \mathrm{C} / 40$ $s$, a final extension at $72^{\circ} \mathrm{C} / 5 \mathrm{~min}$; Gel electrophoresis was at $90 \mathrm{Vol} / 25$ minutes. 


\section{Figure 1}

Optimization of annealing temperature in s-PCR. (A) PCV3, (B) PPV, (C) PCV2. M: DNA ladder $1 \mathrm{~Kb}$ plus, (1):

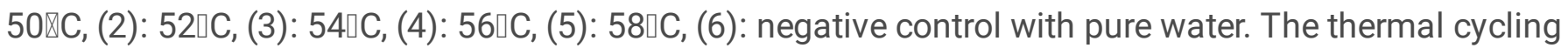
conditions were: $94 \mathrm{oC} / 5 \mathrm{~min} ; 35$ Cycles of $94 \mathrm{oC} / 30 \mathrm{~s}, 56 \mathrm{oC} / 30 \mathrm{~s}$ and $72 \mathrm{oC} / 40 \mathrm{~s}$, a final extension at 72 oC/5 min; Gel electrophoresis was at $90 \mathrm{Vol} / 25$ minutes.

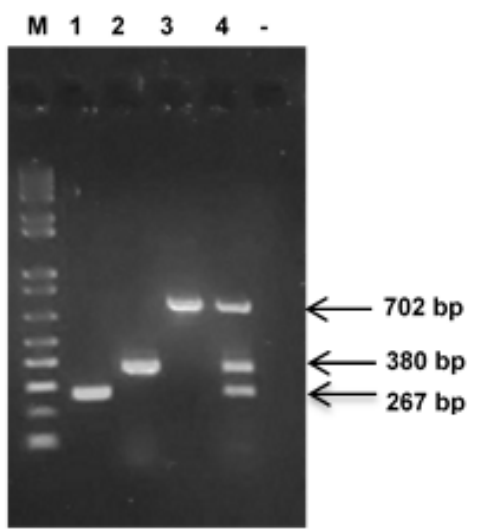

Figure 2. Products of sPCRs and mPCR. (1-3) sPCR: PCV3 276bp (1), (2) PPV 380bp, (3) PCV2 702bp; (4) mPCR of all three targets, (-) negative control with pure water. The thermal cycling conditions were: $9 f^{\circ} \mathrm{C} / 5 \mathrm{~min} ; 35$ Cycles of $94^{\circ} \mathrm{C} / 30 \mathrm{~s}, 56^{\circ} \mathrm{C} / 30 \mathrm{~s}$ and $72{ }^{\circ} \mathrm{C} / 40 \mathrm{~s}$ and a final extension at $72^{\circ} \mathrm{C} / 5 \mathrm{~min}$; Gel electrophoresis was at $90 \mathrm{Vol} / 25$ mimutes.

\section{Figure 2}

Products of sPCRs and mPCR. (1-3) sPCR: PCV3 276bp (1), (2) PPV 380bp, (3) PCV2 702bp; (4) mPCR of all three targets, (-) negative control with pure water. The thermal cycling conditions were: $94 \mathrm{oC} / 5 \mathrm{~min} ; 35$ Cycles of $94 \mathrm{oC} / 30 \mathrm{~s}, 56 \mathrm{oC} / 30 \mathrm{~s}$ and $72 \mathrm{oC} / 40 \mathrm{~s}$ and a final extension at $72 \mathrm{oC} / 5 \mathrm{~min} ; \mathrm{Gel}$ electrophoresis was at 90 $\mathrm{Vol} / 25$ minutes. 

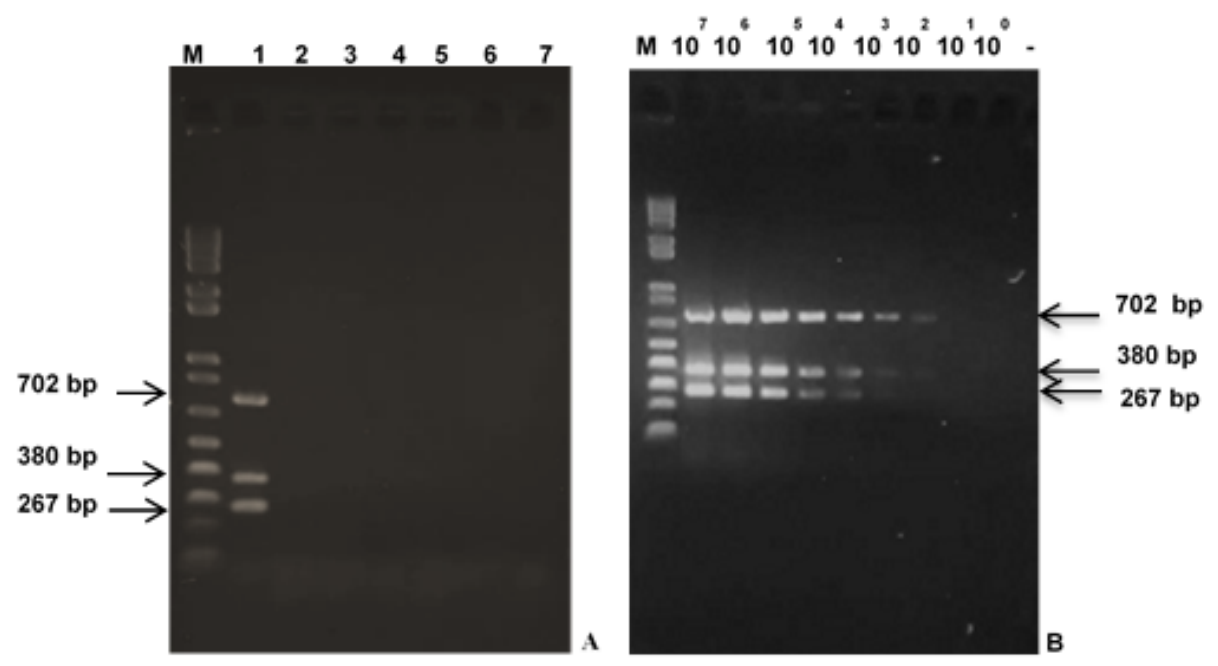

Figure 3. Specificity and sensitivity of the mRCR. (A) Specificity test. M: ladder $1 \mathrm{~Kb}$ plus, (1): positive control, (2): E. coli, (3): Streptococcus suis, (4): Staphylococcus aureus, (5): C. perfringens, (6): Pseudorabies virus, (7): negative control with pure water: B) Detection limit of the mPCR. DNA template of PCV2, PCV3 and PPV were serially diluted and used at $10^{7}-10^{\circ}$ copy/reaction as indicated. M: ladder $1 \mathrm{~Kb}$ plus, (-) negative control with pure water. The thermal cycling conditions were: $94^{\circ} \mathrm{C} / 5 \mathrm{~min} ; 35 \mathrm{Cycles}$ of $94^{\circ} \mathrm{C} / 30 \mathrm{~s}, 56^{\circ} \mathrm{C} / 30 \mathrm{~s}$ and $72^{\circ} \mathrm{C} / 40 \mathrm{~s}$, a final extension at $72{ }^{\circ} \mathrm{C} / 5 \mathrm{~min}$; Gel electrophoresis was at $90 \mathrm{Vol} / 25$ mimutes.

\section{Figure 3}

Specificity and sensitivity of the mRCR. (A) Specificity test. M: ladder $1 \mathrm{~Kb}$ plus, (1): positive control, (2): E. coli, (3): Streptococcus suis, (4): Staphylococcus aureus, (5): C. perfringens, (6): Pseudorabies virus, (7): negative control with pure water. B) Detection limit of the mPCR. DNA template of PCV2, PCV3 and PPV were serially diluted and used at 107-100 copy/reaction as indicated. M: ladder $1 \mathrm{~Kb}$ plus, (-) negative control with pure water. The thermal cycling conditions were: $94 \mathrm{oC} / 5 \mathrm{~min} ; 35$ Cycles of $94 \mathrm{oC} / 30 \mathrm{~s}, 56 \mathrm{oC} / 30 \mathrm{~s}$ and $72 \mathrm{oC} / 40 \mathrm{~s}$, a final extension at $72 \mathrm{oC} / 5 \mathrm{~min}$; Gel electrophoresis was at $90 \mathrm{Vol} / 25$ minutes. 


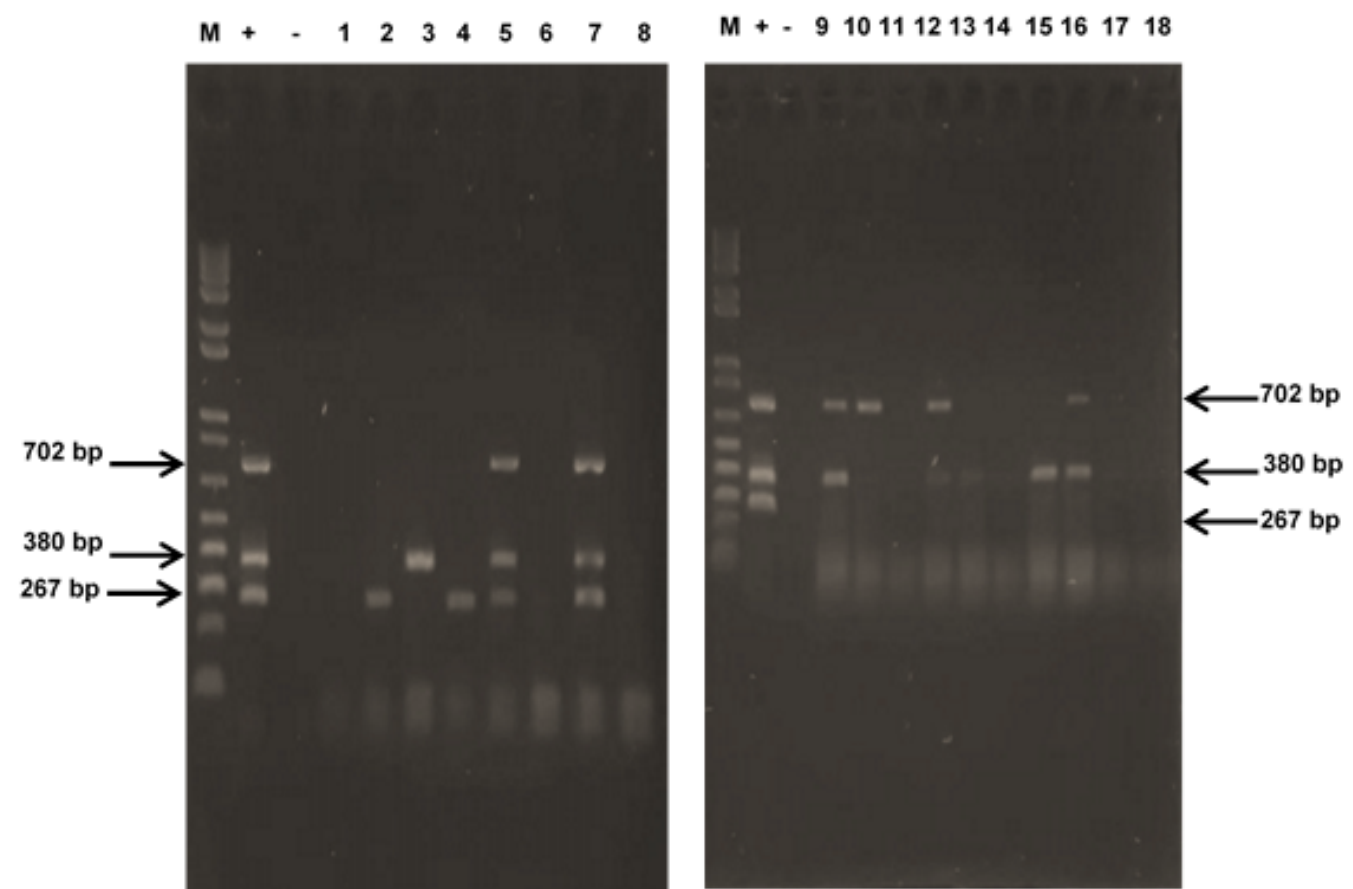

Figure 4. Multiplex PCR test using clinical samples. (1) - (18) Clinical samples. M: DNA ladder I Kb plus, (+) positive control; (-) negative control with pure water. The thermal cycling conditions were: $94^{\circ} \mathrm{C} / 5 \mathrm{~min} ; 35 \mathrm{Cycles}$ of $94^{\circ} \mathrm{C} / 30 \mathrm{~s}, 56^{\circ} \mathrm{C} / 30 \mathrm{~s}$ and $72^{\circ} \mathrm{C} / 40 \mathrm{~s}$, a final extension at $72{ }^{\circ} \mathrm{C} / 5 \mathrm{~min}$; Gel electrophoresis was at $90 \mathrm{Vol} / 25$ minutes.

\section{Figure 4}

Multiplex PCR test using clinical samples. (1) - (18) Clinical samples. M: DNA ladder $1 \mathrm{~Kb}$ plus, (+) positive control; (-) negative control with pure water. The thermal cycling conditions were: 94 oC/5 min; 35 Cycles of 94 $\mathrm{oC} / 30 \mathrm{~s}, 56 \mathrm{oC} / 30 \mathrm{~s}$ and $72 \mathrm{oC} / 40 \mathrm{~s}$, a final extension at $72 \mathrm{oC} / 5 \mathrm{~min}$; Gel electrophoresis was at $90 \mathrm{Vol} / 25$ minutes. 